\title{
ASIDOSIS TUBULAR RENAL DISTAL
}

\author{
Ayu Pathya ${ }^{1)}$, Harnavi Harun²). \\ ${ }^{1}$ Fakultas Kedokteran, Universitas Andalas, RSUP Dr.M.Djamil Padang \\ email: ayupathya@gmail.com
}

Submitted : 17-01-2020, Reviewer: 18-01-2020, Accepted: 19-01-2020

\begin{abstract}
Abstrak
Asidosis tubular renal (ATR) merupakan tubulopati ginjal yang jarang terjadi, dimana terdapat ketidakmampuan ginjal untuk menjaga perbedaan $\mathrm{pH}$ normal antara darah dan lumen tubulus ginjal. Pada kondisi ini terjadi gangguan pengasaman urin disebabkan gangguan reabsorbsi bikarbonat, gangguan ekskresi ion hidrogen, atau keduanya sehingga mengakibatkan asidosis metabolik. ATR ditandai dengan adanya asidosis metabolik dengan senjang anion plasma yang normal, hiperkloremik dan laju filtrasi glomerulus normal. ATR terbagi menjadi 3 tipe utama, yaitu ATR tipe 1 (ATR distal), tipe-2 (ATR proksimal), dan tipe 4 (ATR hiperkalemia). ATR distal merupakan ATR yang disebabkan oleh defek pada tubulus distal ginjal, dimana defek ini menyebabkan gangguan pada sekresi ion hidrogen. Beberapa penelitian menunjukkan bahwa ATR tipe 1 dikaitkan dengan mutasi genetik. Mu tasi genetik herediter dapat autosomal dominan atau autosomal resesif. Gambaran klinis dapat mencakup kelainan pertumbuhan tulang, kelemahan atau kelumpuhan otot, deposit kalsium di ginjal, anoreksia, muntah, konstipasi, diare, dehidrasi, dan poliuria. Telah dilaporkan kasus pasien wanita usia 19 tahun dengan keluhan utama kelemahan di kedua tangan dan kaki. Dari penelusuran klinis dan laboratorium didapatkan hipokalemia dan berdasarkan pendekatan hipokalemia dengan HCO3 - rendah dan pH urine >5,5, diagnosis pada pasien ini ditegakkan sebagai asidosis tubulus renal distal (ATRd).
\end{abstract}

Kata kunci: ATR, ATRd, asidosis metabolik, hiperkloremik, hipokalemia

\begin{abstract}
Renal tubular acidosis (RTA) is a condition caused by the inability of the kidneys to maintain normal $p H$ differences between the blood and tubules lumen of the kidney. Renal tubular acidosis is a rare kidney tubulopathy. In this condition, urine acidification is caused by bicarbonate reabsorption, disruption of hydrogen ion excretion, or both, resulting in metabolic acidosis. RTA is characterized by metabolic acidosis with normal plasma anion, hyperchloremic gaps and normal glomerularfiltration rates. RTA is divided into 3 main types, namely type 1 RTA (distal RTA), type-2 (proximal RTA), and type 4 (hyperkalemia RTA). Distal RTA caused by defects in the distal tubules of the kidney, where these defects cause interference with the hydrogen ion secretion. Several studies have shown that type 1 RTA is associated with genetic mutations. Hereditary genetic mutations can be autosomal dominant or autosomal recessive. Clinical features can include bone growth disorders, muscle weakness or paralysis, calcium deposits in the kidneys, anorexia, vomiting, constipation, diarrhea, dehydration, and polyuria. There has been a reported case of a 19-year-old female patient with a chief complaint weakness in both hands and feet. From clinical and laboratory investigations, it was found that hypopotassium and based on the hypokalemia approach with low HCO3-and urine $p H>5,5$, the diagnosis in this patient was established as a distal renal tubular acidosis (RTAd)
\end{abstract}

Keywords: RTA, RTAd, metabolic acidosis, hypopotassium, hiperchloremic 


\section{PENDAHULUAN}

Asidos is tubular renal (ATR) merupakan suatu tubulopati ginjal, dimana terdapat ketidakmampuan ginjal untuk menjaga perbedaan $\mathrm{pH}$ normal antara darah dan lumen tubulus ginjal. Pada kondisi ini terjadi gangguan pengasaman urin disebabkan gangguan ekskresi ion hidrogen, gangguan reabsorbsi bikarbonat, atau keduanya sehingga mengakibatkan asidosis metabolik. ATR ditandai dengan adanya asidosis metabolik dengan senjang anion plasma normal, hiperkloremik dan laju filtrasi glomerulus normal. ${ }^{1}$

Asidos is tubular renal terbagi menjadi 3 tipe utama, yaitu ATR tipe 1 (ATR distal/ATRd), tipe 2 (ATR proximal/ATRp), dan tipe 4 (ATR hiperkalemia/ATRh) seperti terlihat pada Tabel 1.

Tabel 1: Tipe Asidosis Tubular Renal

\begin{tabular}{|l|c|c|c|}
\hline & $\begin{array}{l}\text { ATR distal } \\
(1)\end{array}$ & $\begin{array}{l}\text { ATR } \\
\text { proximal (2) }\end{array}$ & $\begin{array}{l}\text { ATR } \\
\text { hiperkalemia } \\
(4)\end{array}$ \\
\hline $\begin{array}{l}\text { Defek } \\
\text { primer }\end{array}$ & $\begin{array}{l}\text { Rusaknya } \\
\text { sekresi } \\
\text { distal } \\
\text { NH4+ }\end{array}$ & $\begin{array}{l}\text { Kurangnya } \\
\text { reabsorpsi } \\
\text { HCO3- } \\
\text { proksimal }\end{array}$ & $\begin{array}{l}\text { Kurangnya } \\
\text { sekresi } \\
\text { hormon } \\
\text { aldosteron } \\
\text { atau resistensi } \\
\text { aldosteron }\end{array}$ \\
\hline $\begin{array}{l}\text { Hiperklor } \\
\text { emia }\end{array}$ & Ada & Ada & Ada \\
\hline pH urine & $>5,5$ & $<5,5$ & Tinggi \\
\hline $\begin{array}{l}\text { Kalium } \\
\text { serum }\end{array}$ & Rendah & Rendah & $>15$ \\
\hline $\begin{array}{l}\text { HCO3- } \\
\text { (mmol/L) }\end{array}$ & $<15$ & $<15$ & + \\
\hline $\begin{array}{l}\text { Urine } \\
\text { anion gap }\end{array}$ & + & - & \\
\hline
\end{tabular}

ATR merupakan kasus yang jarang. Berdasarkan penelitian yang pernah dilkakan di Bagian Ilmu Kesehatan Anak FKUI-RSCM, prevalensi ATR terdapat 12 kasus ATR selama 20 tahun (1975-1995). Umumnya ATR terjadi pada anak-anak. Pada kasus dewasa, belum ada literatur yang mendeskripsikan angka pasti kesakitan, , namun sudah ada beberapa kasus ATR yang terjadi pada dewasa terutama ATR tipe 1 atau ATR distal. ${ }^{2}$

Gambaran klinis pada ATR dapat mencakup kelainan pertumbuhan tulang, kelemahan atau kelumpuhan otot, deposit kalsium di ginjal, anoreksia, muntah, konstipasi, diare, dehidrasi, dan poliuria. ATRd dapat disebabkan kelainan primer idiopatik atau sekunder sebagai bagian dari penyakit lain misalnya penyakit sistemik herediter, autoimun, nefrokals inosis, atau akibat paparan dengan obat tertentu seperti amfoterisin B. ${ }^{3}$

Asidos is tubular renal distal merupakan ATR yang disebabkan oleh defek pada tubulus distal ginjal, dimana defek ini menyebabkan gangguan pada sekresi ion hidrogen. Beberapa penelitian menunjukkan bahwa ATRd dikaitkan dengan mutasi genetik. Mutasi genetik herediter dapat autosomal dominan atau autosomal resesif. ${ }^{3}$

Dasar kelainan ATRd ialah gangguan sekresi ion $\mathrm{H}^{+}$pada tubulus distal. Pembentukan $\mathrm{NH}^{+}{ }^{+}$terjadi di tubulus proksimal dari hasil metabolisme asam amino glutamin yaitu NH3 + glukosa + $\mathrm{CO} 2+\mathrm{HCO}^{-}$. $\mathrm{NH} 3$ yang terbentuk akan berikatan dengan ion $\mathrm{H}^{+}$membentuk $\mathrm{NH}^{+}$ yang selanjutnya bergabung dengan $\mathrm{Cl}^{-}$ menjadi $\mathrm{NH} 4 \mathrm{Cl}$ dan kemudian diekskresi bersama urin, sedangkan $\mathrm{HCO}^{-}$yang baru dibentuk masuk sirkulasi sistemik melalui vena renalis. $\mathrm{NH}^{+}$yang tidak keluar bersama urin akan masuk ke hepar melalui sirkulasi sistemik dan dimetabolisme menjadi urea menggunakan sejumlah ion HC03-. ${ }^{4}$

Asidosis metabolik pada ATRd disebabkan gangguan sekresi ion $\mathrm{H}^{+}$dan gangguan produksi $\mathrm{HCO}^{-}$karena produksi $\mathrm{NH}_{4}{ }^{+}$berkurang. Hiperkloremia terjadi karena gangguan ekskresi ion $\mathrm{Cl}^{-}$dalam bentuk NH4Cl. Pada ATRd terjadi gangguan 
pengasaman urin distal sehingga penderita tidak mampu menurunkan $\mathrm{pH}$ urin $<6,0$ selama beban asam dan $<5,5$ selama asidosis sistemik berat. Reabsorbsi $\mathrm{HCO}^{-}$ umumnya normal tapi karena $\mathrm{pH}$ urin tinggi, maka $\mathrm{HCO}^{-}$lolos dari reabsorpsi proksimal. Pembuangan $\mathrm{Na}^{+}$di urin bersama dengan $\mathrm{HCO}^{-}$menyebabkan hipokalemia. ${ }^{5}$

Gejala klinik ATRd umumnya tidak spesifik. Gejala klinis umumnya muncul berkaitan dengan kondisi asidosis metabolik, hiperkloremia, hipokalemia. Hipokalemia pada ATRd biasanya lebih ringan pada ATRp karena pembuangan $\mathrm{HCO}^{-}$dan $\mathrm{Na}^{+}$ pada ATRd lebih sedikit dari pada ATRp. ${ }^{4}$

Gejala umumnya yang terjadi berupa muntah, dehidrasi, konstipasi, poliuria, retardasi pertumbuhan. Gejala lain yang berkaitan dengan hipokalemia seperti kelemahan otot atau parese cukup sering ditemukan. Nefrokalsinosis dapat merupakan komplikasi bila terlambat diobati dan potensial menyebabkan gagal ginjal kronik. Saat ini kondisi nefrokalsinosis jarang ditemukan karena diagnosis dini dan pengobatan adekuat. Rikets dan osteomalasia juga jarang ditemukan kecuali bila tidak diobati. Kehilangan $\mathrm{K}+$ bersama urin menyebabkan hipokalemia ringan sampai berat dengan kelumpuhan berkala bahkan dapat terjadi kegawatan akut dengan gejala muntah, dehidrasi, kolaps sirkulasi, aritmia jantung, lumpuh layu, distres pernapasan, dan mengantuk sampai koma yang membahayakan jiwa. ${ }^{4}$

Nefrokalsinosis dapat terjadi dengan gambaran sinar $\mathrm{X}$ tampak paling cepat pada umur 1 bulan. Kalsifikasi medula ginjal berkembang progresif bila terlambat atau tidak diobati. Pengobatan adekuat sejak dini dapat menghentikan progresifitas kalsifikasi pada bayi. Histologi ginjal umumnya normal pada stadium awal penyakit dan gambaran nefrokalsinosis paling cepat terlihat pada bayi umur 1 bulan. ${ }^{4}$
Pada umumnya diagnosis baru dapat ditegakkan pada saat anak berumur 2 tahun tapi pada beberapa kasus juga ditemukan pada usia dewasa. Diagnos is ATRd ditegakkan berdasarkan riwayat penyakit, gejala klinik, dan laboratorik. Diagnosis dikonfirmasi dengan uji NH4Cl $100 \mathrm{mg} / \mathrm{kg}$ BB /oral yaitu bila sesudah 3-6 jam pemberian $\mathrm{NH} 4 \mathrm{Cl}$ oral, $\mathrm{pH}$ urin $<5,2$ berarti orang nomal sedangkan $\mathrm{pH}$ urin tetap $>5,5$ berarti ATRd. ${ }^{6}$

\section{LAPORAN KASUS}

Pasien perempuan usia 19 tahun datang ke IGD RSUP dr. M. Djamil dengan keluhan lemah pada kedua tangan dan kaki sejak 2 hari sebelum masuk rumah sakit, dengan kelemahan yang lebih berat pada tungkai bawah. Pasien juga mengeluhkan sering buang air kecil yang dirasakan sejak 1 tahun sebelumnya. Sesak nafas, muntah, demam, rasa keram atau kesemutan pada kedua tangan dan kaki disangkal. Riwayat trauma, kejang-kejang riwayat konstipasi tidak ada. Tidak ada riwayat minum obatobatan sebelum keluhan kelemahan anggota badan timbul pertama kali. Tidak ada bukti adanya penyakit gondok. Pasien memiliki adik kandung yang memiliki riwayat keluhan yang sama akibat kekurangan kalium. Pada pemeriksaan fisik didapatkan penurunan kekuatan motorik otot ekstremitas atas dan bawah dengan pemeriksaan sensorik normal. Pada pemeriksaan ekg didapatkan gambaran PR interval memanjang dan gelombang $U$ di seluruh lead.

Pemeriksaan laboratorium darah rutin dalam batas normal dan kadar ureum 30 $\mathrm{mg} / \mathrm{dl}$ dan kreatinin $0,8 \mathrm{mg} / \mathrm{dl}$. Elektrolit serum $\mathrm{Na}$ 136, Kalium 1.7 dan $\mathrm{Cl} 112$. Pemeriksan analisa gas darah menunjukkan asidosis metabolik dengan nilai $\mathrm{HCO} 3-=$ $13,1 \mathrm{mmol} / \mathrm{L}, \quad \mathrm{pH}$ urine didapatkan normal yaitu 6,5 sedangkan kalium urin meningkat 
yaitu $31 \mathrm{mmol} / \mathrm{hari}\left(\mathrm{K}^{+}\right.$urin normal < 15 $\mathrm{mEq} / \mathrm{L}$ ), os molalitas urin $287 \mathrm{mOsm} / \mathrm{kgH}_{2} \mathrm{O}$, dengan $\mathrm{TTKG}=19,11$ yang mengindikasikan bahwa hipokalemia terja di akibat adanya kebocoran kalium pada ginjal. Pada pemeriksaan ultrasonografi (USG) ginjal didapatkan kesan lobulated kidney

Tatalaksana hipokalemia secara umum adalah pemberian kalium oral ataupun intravena. Pada pasien ini diberikan koreksi secara intravena dengan indikasi hipokalemia berat $(<2 \mathrm{mmol} / \mathrm{L})$ dan pasien mengalami perbaikan bermakna secara klinis, ekg dan laboratorium setelah pemberian $\mathrm{KCl}$ intravena. Pilihan terapi pada pasien ATRd, berupa terapi substitusi berupa suplemen $\mathrm{KCl}$ ( $1 \mathrm{mmol} / \mathrm{kg} /$ day $)$, dan suplementasi bikarbonat dengan dosis 10$15 \mathrm{meq} / \mathrm{kgbb} / \mathrm{hari}$.

\section{PEMBAHASAN}

Pasien perempuan usia 19 tahun dirawat di bangsal penyakit dalam RSUP dr. M. Djamil dengan diagnosis akhir paralisis periodik ec hipokale mia ec Asidos is Tubular Renal distal. Diagnos is Asidosis Tubular Renal distal pada pasien ini ditegakkan berdasarkan klinis dan pemeriksaan laboratorium.

Pasien ini datang dengan ke luhan utama kelemahan kedua tangan dan kaki dengan kelemahan yang lebih berat pada tungkai bawah. Hal ini mengarahkan terdapatnya hipokalemia yang merupakan kondisi yang paling sering dengan manifestasi kelemahan otot.

Tidak ada riwayat minum obat-obatan sebelum keluhan kelemahan anggota badan timbul pertama kali. Tidak ada bukti adanya penyakit gondok. Pasien memiliki adik kandung yang juga memiliki riwayat keluhan yang sama akibat kekurangan kalium. Hal ini mendukung suatu kondisi primer dengan dugaan adanya kelainan herediter hipokalemia. Pada pemeriksaan ekg, ditemukan gambaran PR interval memanjang dan gelombang u di seluruh lead yang mengindikasikan sebuah hipokalemia.

Pemeriksaan laboratorium serum didapatkan kesan adanya kalium $1,7 \mathrm{mEq} / \mathrm{L}$, klorida $112 \mathrm{mEq} / \mathrm{L}$, ureum $20 \mathrm{mg} / \mathrm{dl}$, kreatinin $0,8 \mathrm{mg} / \mathrm{dl}$ dengan kesan hipokalemia, hiperkloremia dengan fungsi ginjal normal. Pemeriksan analisa gas darah menunjukkan asidosis metabolik dengan nilai HCO3- $=13,1 \mathrm{mmol} / \mathrm{L}$. Pada pemeriksaan urine didapatkan $\mathrm{pH}$ urine normal, kalium urin meningkat yaitu 31 $\mathrm{mmol} / \mathrm{hari}\left(\mathrm{K}^{+}>15 \mathrm{mEq} / \mathrm{L}\right)$, osmolalitas urin $287 \mathrm{mOsm} / \mathrm{kgH}_{2} \mathrm{O}$, dengan TTKG $=19,11$ yang mengindikasikan bahwa hipokalemia terjadi akibat adanya kebocoran kalium pada ginjal.

Berdasarkan pendekatan alur hipokalemia de ngan $\mathrm{HCO} 3$ - yang rendah, $\mathrm{pH}$ urine $>5,5$ maka ditegakkan pasien ini merupakan sebuah ATR distal. Setelah hipokalemi terkoreksi kelemahan keempat anggota gerak membaik, $\mathrm{HCO} 3$ - mengala mi sedikit peningkatan dengan hasil analisa gas darah asidosis metabolik terkompensasi penuh. Penderita lalu diperbolehkan pulang pada hari perawatan ke- 8 dengan perbaikan klinis, laboratorium dan ekg.

Tatalaksana secara umum pada pasien ini adalah dengan mengatasi hipokalemia dengan pemberian kalium oral ataupun intravena. Pada pasien ini diberikan koreksi secara intravena dengan indikasi hipokalemia berat $(<2 \mathrm{mmol} / \mathrm{L})$ dan pasien mengalami perbaikan bermakna secara klinis, ekg dan laboratorium setelah pemberian $\mathrm{KCl}$ intravena. Pilihan terapi pada pasien ATR distal berupa terapi substitusi berupa suplemen $\mathrm{KCl}$ (1 $\mathrm{mmol} / \mathrm{kg} /$ day), dan suplementasi bikarbonat dengan dosis 10-15meq/kgbb/hari. 


\section{SIMPULAN}

Asidos is tubular renal distal merupakan tubulopati ginjal yang jarang terjadi dengan klinis yang lebih ringan dibanding dengan ATR tipe lainnya. Umumnya pasien datang dengan keluhan yang berhubungan dengan kondisi asidosis metabolik, hipokalemia, dan hiperkloremik yang sering terjadi pada pasien ATR. Tatalaksana pasien ATR secara umum adalah mengatasi kondisi yang terja di berupa koreksi asidosis dengan pemberian suplemen bikarbonat, koreksi hipokalemia dengan pemberian suplemen kalium. Prognosis pada ATR distal umumnya baik selama dilakukan kontrol dan pemberian pengobatan rutin pada kondisi pasien yang berkaitan dengan ATR itu sendiri.

\section{REFERENSI}

1. Basu, G., Sudhakar, G. and Mohapatra, A. (2013). Renal tubular acidosis.

2. Sundung et al.(2003). Gambaran Klinis Asidos is Tubulus Renalis pada Anak. Sari Pediatri,4(4).

3. Alexander, R. and Bitzan, M. (2019). Renal Tubular Acidosis. Pediatric Clinics of North America, 66(1), p.135157.

4. Soleimani, M. and Rastegar, A. (2016). Pathophysiology of Renal Tubular Acidosis: Core Curriculum 2016. American Journal of Kidney Diseases, 68(3), p.488-498.

5. Bergstein JM. Renal tubular acidosis. In: Nelson Textbook of Pediatrics. 16th ed. Philadelphia: WB Saunders and Co; 2000.p.1597-9

6. Batlle D, Haque SK. Genetic causes and mechanisms of distal renal tubular acidosis. Nephrol Dial Transplant 2012;27(10):3691-704. 